\title{
Whole-exome analysis of foetal autopsy tissue reveals a frameshift mutation in OBSL1, consistent with a diagnosis of 3-M Syndrome
}

\author{
Christian R Marshall1,2, Sandra A Farrell ${ }^{3}$, Donna Cushing ${ }^{3}$, Tara Paton ${ }^{1}$, Tracy L Stockley ${ }^{4}$, \\ Dimitri J Stavropoulos ${ }^{4}$, Peter N Ray ${ }^{4}$, Michael Szego ${ }^{1,5}$, Lynette Lau', Sergio L Pereira', Ronald D Cohn ${ }^{6}$, \\ Richard F Wintle ${ }^{1}$, Adel M Abuzenadah ${ }^{7,8}$, Muhammad Abu-Elmagd ${ }^{7,8,9}$, Stephen W Scherer ${ }^{1,2,7^{*}}$
}

From 2nd International Genomic Medicine Conference (IGMC 2013)

Jeddah, Kingdom of Saudi Arabia. 24-27 November 2013

\begin{abstract}
Background: We report a consanguineous couple that has experienced three consecutive pregnancy losses following the foetal ultrasound finding of short limbs. Post-termination examination revealed no skeletal dysplasia, but some subtle proximal limb shortening in two foetuses, and a spectrum of mildly dysmorphic features. Karyotype was normal in all three foetuses $(46, X X)$ and comparative genomic hybridization microarray analysis detected no pathogenic copy number variants.

Results: Whole-exome sequencing and genome-wide homozygosity mapping revealed a previously reported frameshift mutation in the OBSL1 gene (c.1273insA p.T425nfsX40), consistent with a diagnosis of 3-M Syndrome 2 (OMIM \#612921), which had not been anticipated from the clinical findings.

Conclusions: Our study provides novel insight into the early clinical manifestations of this form of 3-M syndrome, and demonstrates the utility of whole exome sequencing as a tool for prenatal diagnosis in particular when there is a family history suggestive of a recurrent set of clinical symptoms.
\end{abstract}

\section{Introduction}

3 -M syndrome is an autosomal recessive disorder characterized by severe pre- and postnatal growth retardation and a characteristic facial appearance, but notably with normal intellect. Typical features include a relatively large head proportionate to the limbs, triangular face, hypoplastic midface, full eyebrows, fleshy nose tip, and long philtrum [1]. Other features can include prominent heels, loose joints, short broad neck, square shoulders, and hyperlordosis. Mutations in three genes are known to cause 3-M syndrome: CUL7 (type 1; OMIM \#273750), OBSL1 (type 2; OMIM \#612921), and CCDC8 (type 3; OMIM \#614205), with roughly $65 \%$ of $3-\mathrm{M}$ syndrome mutations described in CUL7, and $30 \%$ in OBSL1. Functional analysis suggests that

\footnotetext{
* Correspondence: stephen.scherer@sickkids.ca

${ }^{1}$ The Centre for Applied Genomics and Program in Genetics and Genome Biology, The Hospital for Sick Children, Toronto, Ontario, M5G 0A4, Canada Full list of author information is available at the end of the article
}

proteins encoded by these three genes interact in a pathway involved in insulin-like growth factor signalling [2].

We report a first cousin marriage consanguineous couple that experienced three consecutive pregnancy losses following the foetal ultrasound finding of short limbs (Figure 1). Clinical features are summarized in Table 1. The couple was seen in their first pregnancy initially because of an increased nuchal translucency (NT) measurement (5.2 $\mathrm{mm}$ at 13.5 weeks gestation). Amniocentesis showed normal female chromosomes (46, XX). Ultrasound examination at 19 weeks gestation (as estimated by last menstrual period (LMP) date and previous ultrasound) demonstrated normal foetal anatomy, but the femoral and humeral lengths lagged by two weeks. Bone morphology appeared normal, as was a foetal echocardiogram. Repeat ultrasounds at 25 weeks and 28 weeks showed foetal long bones lagging by four weeks and five weeks, respectively. The pregnancy was ended. 


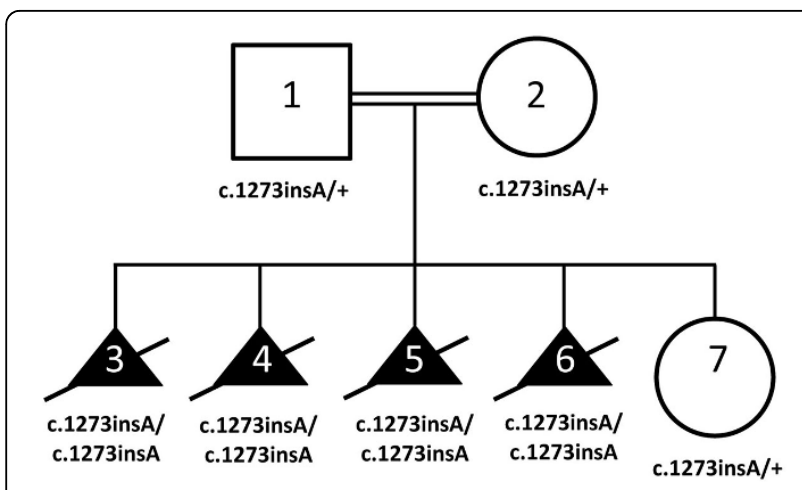

Figure 1 Pedigree with segregation of OBSL1 c.1273insA variant ( $p$. T425nfs X40) in four elective terminations. Individuals 1-5 were genotyped with high-resolution SNP microarray analysis with subsequent homozygosity mapping. Individuals 3 and 4 underwent whole exome sequencing. Individuals 6 and 7 underwent targeted variant testing in the clinical diagnostic laboratory.

Radiographs taken post-termination showed no evidence of a skeletal dysplasia. This fetus was not examined by a geneticist and nor was there an autopsy.

In the couple's second pregnancy, the NT measured $2.8 \mathrm{~mm}$ at 13 weeks gestation. Foetal ultrasound at 18 weeks gestation, by LMP and previous ultrasound, showed foetal long bones lagging by two weeks. Bone morphology was again normal. Ultrasound at 22 weeks showed foetal long bones lagging by three weeks. The pregnancy was ended. Microarray analysis detected no pathogenic variants. On autopsy, the foetus was mildly dysmorphic with increased bitemporal diameter, slightly upslanting palpebral fissures, prominent and mildly proptotic eyes, low set ears, mild nuchal edema, a proportionately large head, proximal limb shortening, and prominent heel pads. Autopsy was otherwise unremarkable, including microscopy of bones. Postmortem radiographs showed no evidence of a skeletal dysplasia.

In the third pregnancy, the NT measured $3.5 \mathrm{~mm}$ at 11 weeks gestation. Ultrasound at 20 weeks gestation, by LMP and previous ultrasound, showed foetal long bones lagging by two weeks. The pregnancy was ended. On autopsy, the foetus showed a triangular face associated with hypoplasia of maxillary bones and mandibles, synophrys, prominent eyes, and long philtrum. Proximal limbs were shortened. Karyotype showed normal female chromosomes (46, XX).

Given the couple's history of consanguinity and no definitive clinical explanation for the medical symptoms, DNA samples from all three foetuses and parents were tested by whole-exome sequence analysis as part of a clinical research study. Assuming an autosomal recessive model of inheritance, exome sequencing was attempted with the goal of uncovering previously unknown mutations in coding regions of genes. This approach has been shown particularly effective when combined with genome-wide microarray genotyping or conventional linkage analysis to identify regions of homozygosity in consanguineous pedigrees [3-7]. We report here the discovery of a previously known frameshift mutation in OBSL1, providing a diagnosis of 3-M Syndrome 2, which would explain the foetal long bone ultrasound findings. This diagnosis was not anticipated based on the prenatal clinical observations alone. The counselling and diagnostic issues raised by this discovery are discussed.

\section{Materials and methods}

Subjects were consented for research study at The Hospital for Sick Children (Toronto, Canada; REB File No.: 1000007909).

\section{Karyotyping, genome wide SNP genotyping, homozygosity mapping, and copy number variation (CNV) analysis}

DNA samples from all family members were isolated from whole blood or autopsy material. Karyotypes were performed on a clinical basis using standard techniques. Samples were genotyped for 2,443,177 markers using the Infinium HumanOmni2.5-quad v1.0 BeadChip (Illumina Inc., San Diego, CA, USA) according to the manufacturer's protocol. Briefly, $200 \mathrm{ng}$ of DNA $(4 \mu \mathrm{L}$ at $50 \mu \mathrm{g} / \mu \mathrm{L})$ was independently amplified, labeled, and hybridized to BeadChip microarrays then scanned with default settings using an Illumina iScan. Analysis and intra-chip normalization of resulting image files was performed using Illumina's GenomeStudio Genotyping Module software v.2011 with default parameters. Genotype calls were generated using the vendor-provided genotype cluster definitions file (HumanOmni2.5-4v1_H.egt, generated using HapMap project DNA samples) with a Gencall cutoff of 0.15 . The CNVPartition v.3.1.6 module in GenomeStudio was used for CNV analysis and homozygosity mapping. Potential CNVs were compared to control data in the Database of Genomic Variants (http://projects.tcag.ca/variation) [8,9] and also examined for recurrence in all three affected foetuses. Approximately 700,000 markers were also analyzed for shared regions of homozygosity shared by the three affected offspring using HomozygosityMapper [10].

\section{Whole exome sequencing}

Paired-end (75 + 35 nucleotide) exome sequencing was performed on samples from two affected foetuses (TCAG0322-003 and TCAG0322-004) on a SOLiD $5500 x l$ (Life Technologies, Carlsbad, CA, USA) with target enrichment using the SureSelect $50 \mathrm{Mb}$ Human All Exon capture kit V3 (Agilent Technologies, Santa Clara, CA, USA). Briefly, $3 \mu \mathrm{g}$ of genomic DNA was sonicated to approximately $200 \mathrm{bp}$ using a Covaris-S2 (Covaris Inc., Woburn, MA, USA). Fragmented DNA was end-repaired 
Table 1 Phenotypic Features of 3-M syndrome in three affected foetuses

\begin{tabular}{|c|c|c|c|c|c|}
\hline CATEGORY & SUBCATEGORY & FEATURES & $3^{a}$ & $4^{b}$ & $5^{b}$ \\
\hline \multirow[t]{4}{*}{ Growth } & Height & Short stature & + & + & + \\
\hline & Weight & Low birth weight & NA & NA & NA \\
\hline & Other & Intrauterine growth retardation & + & + & + \\
\hline & & Postnatal growth retardation & NA & NA & NA \\
\hline \multirow[t]{13}{*}{ Head and Neck } & Head & Frontal bossing & ND & + & + \\
\hline & & Increased relative head circumference & ND & + & + \\
\hline & Face & Triangular face & ND & + & + \\
\hline & & Pointed, prominent chin & ND & + & + \\
\hline & & Hypoplastic midface & ND & + & + \\
\hline & & Long philtrum & ND & ND & + \\
\hline & Eyes & Full eyebrows & NA & NA & NA \\
\hline & Nose & Fleshy, upturned nose & ND & ND & ND \\
\hline & & Low nasal bridge & ND & + & + \\
\hline & & Depressed nasal root & ND & ND & ND \\
\hline & & Anteverted nares & ND & ND & + \\
\hline & Mouth & Full lips & NA & NA & NA \\
\hline & Neck & Short neck & NA & NA & NA \\
\hline Respiratory & & Neonatal respiratory distress & NA & NA & NA \\
\hline \multirow[t]{5}{*}{ Chest } & External Features & Short, wide, flat thorax & NA & NA & NA \\
\hline & & Pectus excavatum & NA & NA & NA \\
\hline & Ribs, Sternum, Clavicles and Scapulae & High, square shoulders & NA & NA & NA \\
\hline & & Rib hypoplasia & NA & NA & NA \\
\hline & & Winged scapulae & NA & NA & NA \\
\hline Abdomen & External Features & Enlarged abdomen & NA & NA & NA \\
\hline \multirow[t]{2}{*}{ Genitourinary } & External Genitalia (Male) & Hypospadias & NA & NA & NA \\
\hline & & Small testes & NA & NA & NA \\
\hline \multirow[t]{13}{*}{ Skeletal } & General & Delayed bone age & + & + & + \\
\hline & & Joint hypermobility & NA & NA & NA \\
\hline & & Joint dislocation & NA & NA & NA \\
\hline & Skull & Dolichocephaly & ND & ND & ND \\
\hline & Spine & Tall vertebral bodies & ND & ND & ND \\
\hline & & Hyperlordosis & NA & NA & NA \\
\hline & Pelvis & Hip dislocation & NA & NA & NA \\
\hline & & Small pelvis & NA & NA & NA \\
\hline & Limbs & Long, slender tubular bones & NA & + & + \\
\hline & Hands & Short fifth fingers & NA & NA & NA \\
\hline & & Clinodactyly & NA & NA & NA \\
\hline & Feet & Prominent heels & NA & + & + \\
\hline & & Pes planus & NA & NA & NA \\
\hline Skin, Nails, Hair & Hair & Full eyebrows & NA & NA & NA \\
\hline \multirow[t]{2}{*}{ Neurologic } & Central Nervous System & Normal intelligence & NA & NA & NA \\
\hline & & Spina bifida occulta & NA & NA & NA \\
\hline
\end{tabular}

altrasound and radiograph; ${ }^{b}$ formal autopsy performed; NA (Not applicable); ND (Not done or tested) 
and purified with Agencourt Ampure XP beads (Beckman Coulter, Inc.). Fragments were size selected to $\sim 200 \mathrm{bp}$ through electrophoresis on a $\%$ agarose E-gel (Life Technologies), and the recovered DNA amplified using SureSelect pre-capture primers and Herculase II Fusion Enzyme (Agilent) with conditions of $72^{\circ} \mathrm{C}$ for 20 minutes, $95^{\circ} \mathrm{C}$ for 5 minutes, followed by 10 cycles of $95^{\circ} \mathrm{C}$ for 15 seconds, $54^{\circ} \mathrm{C}$ for 45 seconds, $70^{\circ} \mathrm{C}$ for 60 seconds and a subsequent final extension of $70^{\circ} \mathrm{C}$ for five minutes. Hybridization with biotinylated RNA baits corresponding to target regions was carried out using $500 \mathrm{ng}$ of prepared library for 24 hours at $65^{\circ} \mathrm{C}$, and captured DNA recovered with streptavidin coated magnetic beads. The recovered library was amplified and barcode sequencing tags incorporated by amplification with Herculase II Fusion Enzyme and SureSelect barcoding primers under conditions of $95^{\circ} \mathrm{C}$ for 5 minutes, then $95^{\circ} \mathrm{C}$ for 15 seconds, $54^{\circ} \mathrm{C}$ for 45 seconds, $70^{\circ} \mathrm{C}$ for 60 seconds for 9 cycles, and a subsequent final extension of $70^{\circ} \mathrm{C}$ for 5 minutes. Equimolar quantities of six barcoded exome libraries were pooled for preparation of templated beads by emulsion PCR using the Life Technology EZ Bead System. Beads were loaded on six lanes of a 5500 flowchip for paired-end sequencing as recommended by the manufacturer.

\section{Read mapping, variant calling and annotation}

Paired end reads for both samples were combined and mapped to the reference human genome (UCSC hg19) using BFAST (http://bfast.sourceforge.net) [11]. Indel and SNP calls were made using GATK version1.0.5506 and recommended parameters [12]. Base quality score recalibration optimized to SOLiD 5500xl was used to remove reference bias. All no-call reads were removed from the analysis, and if a reference base was inserted the base quality was set to zero and the inserted reference nucleotide set to "N". Variant recalibration with external datasets including HapMap, 1000 genomes, and dbSNP 129 was performed before using Beagle [13], implemented in GATK, to refine genotypes. Variants were filtered using cutoffs from GATK results of QD (Quality by Depth) $>5$ and SB (Strand Bias) $<0.01$ to minimize false positive detection. Variant calls were designated as novel if they did not appear in the external datasets listed above. Variants were annotated using SIFT 4.0.3 [14] to determine if the substitution was predicted to be deleterious to protein function.

\section{Sequence validation}

The OBSL1 variant was validated using standard Sanger sequencing. A 453 bp region of OBSL1 containing the variant was PCR-amplified using the primers OBSL1-F (5'- GCACAGCATTCTCTCCTTCC -3') and OBSL1-R (5'- CCAGAGCCCTCTCTTGTCTC - 3') using 50n g of genomic DNA. The $25 \mu \mathrm{l}$ reaction consisted of $22 \mu \mathrm{l} \mathrm{PCR}$ master mix (7.8 $\mu \mathrm{l}$ water, $6.3 \mu \mathrm{l} 5 \mathrm{M}$ betaine, $3.1 \mu \mathrm{l} 10 \mathrm{x}$ PCR buffer (Life Technologies), $1.5 \mu \mathrm{l} 25 \mathrm{mM} \mathrm{MgCl} 2,3.1$ $\mu \mathrm{l} 2 \mathrm{mM}$ dNTP mix, $0.2 \mu \mathrm{l}$ AmpliTaq DNA polymerase (Life Technologies)), $1 \mu \mathrm{l}$ each primer $(50 \mathrm{ng} / \mu \mathrm{l})$ and $1 \mathrm{ul}$ DNA (50 ng/ $\mu \mathrm{l})$. Cycling conditions were $95^{\circ} \mathrm{C}(10 \mathrm{~min})$ followed by 36 cycles of $95^{\circ} \mathrm{C}(15 \mathrm{sec})-60^{\circ} \mathrm{C}(30 \mathrm{sec})-$ $72^{\circ} \mathrm{C}(1 \mathrm{~min})$.

\section{Results}

Homozygosity mapping using high-resolution genotyping revealed two regions that reached significance: one of 9.7 $\mathrm{Mb}$ at chromosome $2 \mathrm{q} 34-\mathrm{q} 35$, and one of $35.7 \mathrm{Mb}$ at chromosome 8q13.2-q22.3 present for all three affected foetuses (Additional File 1, Table S1 and Figure S1). These regions were both heterozygous in the biological parents. Our CNV analysis did not reveal any potentially pathogenic alterations for any of the three foetuses (data not shown).

Exome sequencing yielded a total of 19,838 genic variants for further investigation (Additional File 1, Table S2). We prioritized rare $(<1 \%$ allele frequency) or novel variants that were either loss of function (frameshift, splice mutations, stop mutations) or missense variants that were predicted to be damaging and that resided within the regions of shared homozygosity described above. At total of 13 variants (Additional File 1, Table S3) were detected that fit these criteria involving nine genes (SPAG16, MARCH4, GPBAR1, USP37, ANKZF1, SPEG, OBSL1, SLCO5A1, DCAF13).

The most interesting candidate was a homozygous insertion variant in the gene OBSL1 (OMIM \#610991) on chromosome 2 (c.1273insA), resulting in a frameshift and premature stop (p.T425nfsX40). This frameshift variant of OBSL1 has been previously observed in patients with $3-\mathrm{M}$ syndrome $[15,16]$ and in those studies was detected in cases with a similar ancestry to the family in this study. Moreover, the finding of a recessive loss of function mutation in OBSL1 called our attention to 3-M syndrome being similar to the phenotype observed in the foetuses. Despite the majority of $3 \mathrm{M}$ core clinical features not manifesting completely until later in life (Table 1 ), the skeletal phenotype observed in the foetuses ultimately made a prenatal diagnosis of 3-M syndrome plausible. The variant was validated by Sanger sequencing, and demonstrated segregation consistent with an autosomal recessive model of disease inheritance (i.e., heterozygous in both parents, homozygous in all three foetuses).

At the time of our initial research findings we learned that the female research subject was pregnant for the fourth time. Clinical confirmation of the research finding though approved molecular diagnostic gene testing was denied by the provincial (Ontario) Ministry of Health that oversees clinical testing since in this jurisdiction it 
will not authorise testing on material from a deceased individual. Through consultation with attending physicians and ethicists genetic counselling was eventually offered based on the research result and a sample was taken for clinical testing in the diagnostic laboratory at The Hospital for Sick Children. The clinical testing revealed a homozygous variant genotype, consistent with an affected child. This pregnancy was eventually ended. The fifth pregnancy was similarly tested in the clinical diagnostic laboratory, indicating the foetus was a carrier of the OBSL1 mutation. This was consistent with the normal developmental pattern subsequently observed.

\section{Discussion}

Prenatal diagnosis of 3-M syndrome based on ultrasound is findings is unreliable, given that intrauterine growth retardation has many causes and is not specific to this syndrome. Additionally, although growth retardation of long bones in utero has been reported [17], this finding is not always seen in children with 3-M syndrome. As well, the degree of long bone growth lag of these fetuses was relatively mild and might have been missed had there not been an increased NT measurement to cause careful scrutiny of the fetal ultrasound results in the first pregnancy. Although in this family, at autopsy, the second and third foetuses were noted to have physical findings seen in 3-M syndrome (large head, heel pads, prenatal growth retardation, triangular face, hypoplastic midface and long philtrum) these findings were not specific enough by themselves to consider a differential diagnosis of 3-M syndrome.

Recently, exome sequencing has been used to reveal a mutation in the CUL7 gene in a young adult with a previously undiagnosed growth disorder [18]. This observation echoes our finding that the spectrum of growth disorders represented by the genes of the OBSL1/CUL7/ $C C D C 8$ growth factor signalling pathway might be broader than previously appreciated [19]. While CUL7 and OBSL1 account for $\sim 94 \%$ of known 3-M syndrome cases [1], the remaining $6 \%$ (at least partly accounted for by $C C D C 8$ mutations) of undiagnosed cases suggests that additional genes and perhaps regulatory (non-coding) mutations in known genes are yet to be implicated.

Individual research results normally need to meet four threshold conditions prior to disclosure to research subjects. The results should have significant health implications for the participant, be actionable, and the test needs to be analytically valid. Furthermore, during the informed consent process the possibility of the return of individual results needs to be addressed and agreed upon by the research participant. In this study, we could not achieve the threshold of analytic validity, which in this case meant the test had to be performed in a licenced and accredited laboratory as required by legislation. Although our results were validated by whole exome and Sanger sequencing, respectively, the initial genetic experiment was performed in a research laboratory. To achieve analytic validity, in most jurisdictions, a validated genetic test in a clinical laboratory would have been required. We also had the added complication of provincial rules regarding testing of a sample from a deceased foetus. Given that the female research subject was pregnant for the fourth time and had already received abnormal ultrasound results our multidisciplinary team decided to disclose our research findings to the family through a hospital genetic counsellor. Our reasoning was that by providing this information to the research subject, she could then opt to undergo clinical prenatal testing for 3$\mathrm{M}$ syndrome, an analytically valid test, which would not otherwise be clearly indicated at an early gestation by ultrasound findings. We were concerned that if we waited to achieve analytic validity, the research subject would likely have terminated her fourth pregnancy before the clinical diagnostic results were available. By returning the results back to the research subject, she was able to have a clinical test performed and make a more informed decision about her pregnancy. When the fourth foetus also was found to have the homozygous mutations, the pregnancy was ended at an earlier gestation than had occurred in the previously affected pregnancies, with the clear understanding that the foetus was affected.

Several regions of the world including some Middle Eastern gulf countries such as Saudi Arabia can have rates of consanguinity that can exceed $50 \%$ of unions necessitating implementation of clinical genetic programs [20-22]. Such high consanguinity has been shown to have serious medical impact on the populations with a high incidence of congenital malformations and mental retardation within the consanguineous families. This case illustrates how next generation sequencing, either whole exome or genome sequencing, can have power to establish prenatal diagnoses in foetuses that present with clinical phenotypes that do not provide enough specific details to establish a diagnosis based on ultrasound and clinical findings alone. In turn, knowledge of the mutation has provided the family with the opportunity to make informed decisions about pre-implantation testing/in vitro fertilization and/or to perform directed mutation analysis from foetal tissue via CVS or amniocentesis. The application of exome or whole genome sequencing in pediatric and adult disorders can raise different issues ranging from incidental or secondary findings [23], implications for genetic counselling and clinical management [24] to the direction of new treatment options [25]. We believe that whole genome sequencing thus represents a particular powerful diagnostic tool for families in areas with high incidence of consanguinity and has the potential to provide highly specific information to families and health care providers that will 
impact medical management beyond the current available technologies and diagnostic measures.

\section{Additional material}

$$
\text { Additional file 1: Supplementary Material }
$$

\section{Competing Interests}

The authors declare that they have no competing interests.

\section{Acknowledgements}

This study was funded by the University of Toronto McLaughlin Centre and conducted at The Centre for Applied Genomics (TCAG). TCAG is supported by Genome Canada, the Ontario Genomics Institute, the Canada Foundation for Innovation, the Government of Ontario, and the SickKids Centre for Genetic Medicine. We are grateful to the staff of the SickKids Molecular Diagnostics laboratory, and the Informatics, Sequencing and Microarray Facilities of The Centre for Applied Genomics, for technical assistance.

\section{Declarations}

Publication fees were paid by the Centre of Excellence in Genomic Medicine Research of King Abdulaziz University.

This article has been published as part of BMC Genomics Volume 16 Supplement 1, 2015: Selected articles from the 2nd International Genomic Medical Conference (IGMC 2013): Genomics. The full contents of the supplement are available online at http://www.biomedcentral.com/ bmcgenomics/supplements/16/S1

\section{Authors' details}

${ }^{1}$ The Centre for Applied Genomics and Program in Genetics and Genome Biology, The Hospital for Sick Children, Toronto, Ontario, M5G 0A4, Canada. ${ }^{2}$ McLaughlin Centre and Department of Molecular Genetics, the University of Toronto, Ontario, M5S 2J7, Canada. ${ }^{3}$ Genetics, Trillium Health Partners, Credit Valley Hospital, Mississauga, Ontario, L5M 2N1, Canada. ${ }^{4}$ Department of Paediatric Laboratory Medicine, The Hospital for Sick Children, Toronto, Ontario, M5G 1X8, Canada. ${ }^{5}$ Joint Centre for Bioethics and Department of Family and Community Medicine, the University of Toronto, Ontario, M5T 1P8, Canada. ${ }^{6}$ Division of Clinical and Metabolic Genetics, The Hospital for Sick Children, Toronto, Ontario, Canada. ${ }^{7}$ Centre of Excellence in Genomic Medicine Research, King Abdulaziz University, 80216 Jeddah 21589, Kingdom of Saudi Arabia. ${ }^{8}$ KACST Technology Innovation Center in Personalized Medicine, King Abdulaziz University, Jeddah, Kingdom of Saudi Arabia. ${ }^{9}$ Zoology Department, Faculty of Science, Minia University, Minia, Egypt.

Published: 15 January 2015

\section{References}

1. Holder-Espinasse M: 3-M Syndrome. In GeneReviews. University of Washington. Seattle;Pagon RA, Bird TD, Dolarn CR 1993:.

2. Hanson D, Murray PG, Black GC, Clayton PE: The genetics of 3-M syndrome: unravelling a potential new regulatory growth pathway. Horm Res Paediatr 2011, 76(6):369-78.

3. Bilgüvar K, Oztürk AK, Louvi A, Kwan KY, Choi M, Tatli B, Yalnizoğlu D, Tüysüz B, Cağllayan AO, Gökben S, Kaymakçalan H, Barak T, Bakircioğlu M, Yasuno K, Ho W, Sanders S, Zhu Y, Yilmaz S, Dinçer A, Johnson MH, Bronen RA, Koçer N, Per H, Mane S, Pamir MN, Yalçinkaya C, Kumandaş S, Topçu M, Ozmen M, Sestan N, Lifton RP, State MW, Günel M: Whole-exome sequencing identifies recessive WDR62 mutations in severe brain malformations. Nature 2010, 467(7312):207-10.

4. Choi M, Scholl UI, Ji W, Liu T, Tikhonova IR, Zumbo P, Nayir A, Bakkaloğ lu A, Ozen S, Sanjad S, Nelson-Williams C, Farhi A, Mane S, Lifton RP: Genetic diagnosis by whole exome capture and massively parallel DNA sequencing. Proc Natl Acad Sci U S A 2009, 106(45):19096-101.

5. Krawitz PM, Schweiger MR, Rödelsperger C, Marcelis C, Kölsch U, Meisel C, Stephani F, Kinoshita T, Murakami Y, Bauer S, Isau M, Fischer A, Dahl A, Kerick M, Hecht J, Köhler S, Jäger M, Grünhagen J, de Condor BJ, Doelken S, Brunner HG, Meinecke P, Passarge E, Thompson MD, Cole DE, Horn D,
Roscioli T, Mundlos S, Robinson PN: Identity-by-descent filtering of exome sequence data identifies PIGV mutations in hyperphosphatasia mental retardation syndrome. Nat Genet 2010, 42(10):827-9.

6. Otto EA, Hurd TW, Airik R, Chaki M, Zhou W, Stoetzel C, Patil SB, Levy S, Ghosh AK, Murga-Zamalloa CA, van Reeuwijk J, Letteboer SJ, Sang L, Giles RH, Liu Q, Coene KL, Estrada-Cuzcano A, Collin RW, McLaughlin HM, Held S, Kasanuki JM, Ramaswami G, Conte J, Lopez I, Washburn J, Macdonald J, Hu J, Yamashita Y, Maher ER, Guay-Woodford LM, Neumann HP, Obermüller N, Koenekoop RK, Bergmann C, Bei X, Lewis RA, Katsanis N, Lopes V, Williams DS, Lyons RH, Dang CV, Brito DA, Dias MB, Zhang X, Cavalcoli JD, Nürnberg G, Nürnberg P, Pierce EA, Jackson PK, Antignac C, Saunier S, Roepman R, Dollfus H, Khanna H, Hildebrandt F: Candidate exome capture identifies mutation of SDCCAG8 as the cause of a retinal-renal ciliopathy. Nat Genet 2010, 42(10):840-50.

7. Walsh T, Shahin H, Elkan-Miller T, Lee MK, Thornton AM, Roeb W, Abu Rayyan A, Loulus S, Avraham KB, King MC, Kanaan M: Whole exome sequencing and homozygosity mapping identify mutation in the cell polarity protein GPSM2 as the cause of nonsyndromic hearing loss DFNB82. Am J Hum Genet 2010, 87(1):90-4.

8. lafrate AJ, Feuk L, Rivera MN, Listewnik ML, Donahoe PK, Qi Y, Scherer SW Lee C: Detection of large-scale variation in the human genome. Nat Genet 2004, 36(9):949-51.

9. Macdonald JR, Ziman R, Yuen RK, Feuk L, Scherer SW: The Database of Genomic Variants: a curated collection of structural variation in the human genome. Nucleic Acids Res 2014, 42(1):D986-92.

10. Seelow D, Schuelke M, Hildebrandt F, Nürnberg P: HomozygosityMapperan interactive approach to homozygosity mapping. Nucleic Acids Res 2009, 37(Web Server issue):W593-9.

11. Homer N, Merriman B, Nelson SF: BFAST: an alignment tool for large scale genome resequencing. PLoS One 2009, 4(11):e7767.

12. DePristo MA, Banks E, Poplin R, Garimella KV, Maguire JR, Hartl C, Philippakis AA, del Angel G, Rivas MA, Hanna M, McKenna A, Fennell TJ, Kernytsky AM, Sivachenko AY, Cibulskis K, Gabriel SB, Altshuler D, Daly MJ: A framework for variation discovery and genotyping using nextgeneration DNA sequencing data. Nat Genet 2011, 43(5):491-8.

13. Browning $B L$, Browning SR: A fast, powerful method for detecting identity by descent. Am J Hum Genet 2011, 88(2):173-82.

14. Ng PC, Henikoff S: SIFT: Predicting amino acid changes that affect protein function. Nucleic Acids Res 2003, 31(13):3812-4.

15. Hanson D, Murray PG, Sud A, Temtamy SA, Aglan M, Superti-Furga A, Holder SE, Urquhart J, Hilton E, Manson FD, Scambler P, Black GC, Clayton PE: The primordial growth disorder 3-M syndrome connects ubiquitination to the cytoskeletal adaptor. OBSL1. Am J Hum Genet 2009, 84(6):801-6.

16. Huber C, Fradin M, Edouard T, Le Merrer M, Alanay $Y$, Da Silva DB, David A, Hamamy H, van Hest L, Lund AM, Michaud J, Oley C, Patel C, Rajab A, Skidmore DL, Stewart H, Tauber M, Munnich A, Cormier-Daire V: OBSL1 mutations in 3-M syndrome are associated with a modulation of IGFBP2 and IGFBP5 expression levels. Hum Mutat 2010, 31(1):20-6.

17. Meo F, Pinto V, D'Addario V: 3-M syndrome: a prenatal ultrasonographic diagnosis. Prenat Diagn 2000, 20(11):921-3.

18. Dauber A, Stoler J, Hechter E, Safer J, Hirschhorn JN: Whole exome sequencing reveals a novel mutation in CUL7 in a patient with an undiagnosed growth disorder. J Pediatr 2013, 162(1):202-4.e1.

19. Hanson D, Murray PG, Coulson T, Sud A, Omokanye A, Stratta E, Sakhinia F, Bonshek C, Wilson LC, Wakeling E, Temtamy SA, Aglan M, Rosser EM, Mansour S, Carcavilla A, Nampoothiri S, Khan WI, Banerjee I, Chandler KE, Black GC, Clayton PE: Mutations in CUL7, OBSL1 and CCDC8 in 3-M syndrome lead to disordered growth factor signalling. J Mol Endocrinol 2012, 49(3):267-75.

20. El-Hazmi MA, Al-Swailem AR, Warsy AS, Al-Swailem AM, Sulaimani R, AlMeshari AA: Consanguinity among the Saudi Arabian population. J Med Genet 1995, 32(8):623-6.

21. Al Husain M, Al Bunyan M: Consanguineous marriages in a Saudi population and the effect of inbreeding on prenatal and postnatal mortality. Ann Trop Paediatr 1997, 17(2):155-60.

22. Abdulrazzaq YM, Bener A, al-Gazali LI, al-Khayat Al, Micallef R, Gaber T: A study of possible deleterious effects of consanguinity. Clin Genet 1997, 51(3):167-73.

23. Green RC, Berg JS, Grody WW, Kalia SS, Korf BR, Martin CL, McGuire AL, Nussbaum RL, O'Daniel JM, Ormond KE, Rehm HL, Watson MS, Williams MS, 
Biesecker LG: ACMG recommendations for reporting of incidental findings in clinical exome and genome sequencing. Genet Med 2013, 15(7):565-74.

24. Jiang YH, Yuen RK, Jin X, Wang M, Chen N, Wu X, Ju J, Mei J, Shi Y, He M, Wang G, Liang J, Wang Z, Cao D, Carter MT, Chrysler C, Drmic IE, Howe JL, Lau L, Marshall CR, Merico D, Nalpathamkalam T, Thiruvahindrapuram B, Thompson A, Uddin M, Walker S, Luo J, Anagnostou E, Zwaigenbaum L, Ring RH, Wang J, Lajonchere C, Wang J, Shih A, Szatmari P, Yang H, Dawson G, Li Y, Scherer SW: Detection of clinically relevant genetic variants in autism spectrum disorder by whole-genome sequencing. Am J Hum Genet 2013, 93(2):249-63.

25. Rilstone JJ, Alkhater RA, Minassian BA: Brain dopamine-serotonin vesicular transport disease and its treatment. N Engl J Med 2013, 368(6):543-50.

doi:10.1186/1471-2164-16-S1-S12

Cite this article as: Marshall et al:: Whole-exome analysis of foetal autopsy tissue reveals a frameshift mutation in OBSL1, consistent with a diagnosis of 3-M Syndrome. BMC Genomics 2015 16(Suppl 1):S12.

\section{Submit your next manuscript to BioMed Central} and take full advantage of:

- Convenient online submission

- Thorough peer review

- No space constraints or color figure charges

- Immediate publication on acceptance

- Inclusion in PubMed, CAS, Scopus and Google Scholar

- Research which is freely available for redistribution

Submit your manuscript at www.biomedcentral.com/submit
Ciomed Central 